\title{
EXPLORING INFORMATION COMMUNICATIONS TECHNOLOGY (ICT) INFUSED MICROTEACHING MODULE AT A UNIVERSITY OF TECHNOLOGY IN SOUTH AFRICA
}

\author{
Paseka Patric Mollo \\ Department of Educational and Professional Studies, Faculty of Humanities, \\ Central University of Technology, Free State, Bloemfontein 9300 (South Africa)
}

\begin{abstract}
The concept of microteaching was first introduced in the 1960s at Stanford University in the USA. From there onwards most universities, universities of technologies and teacher training institutions are using microteaching as a technique to train prospective teachers to function within their teaching and learning environment. At the Central University of Technology (CUT) in South Africa, Microteaching is a compulsory module for all student teachers registered for a Bachelor of Education degree. This module aims to equip student teachers with teaching skills, teaching strategies, teaching styles and confidence needed within the classroom environment. However, with the large numbers of student teacher enrollments at CUT, the delivery of this indispensable teacher training module was faced with a lot of challenges. The challenges, among others are the inadequacies of microteaching laboratories; student teacher peer involvement and evaluation of micro-lessons by lecturers. These challenges called for a review of the present model for microteaching. ICT was infused with microteaching model to solve the above challenges. This article explores the perceptions of CUT student teachers towards the ICT infused microteaching. A questionnaire to obtain student teachers' views about ICT infused microteaching was used to collect data. The findings indicated that student teachers enjoyed the use of this approach and most of the challenges associated with microteaching were solved.
\end{abstract}

Keywords: Information communications technology, microteaching, micro-lessons, student teachers, teacher education.

\section{Introduction}

Microteaching is a teacher training technique currently practiced worldwide by universities and / or teacher training institutions. The history of this teacher training technique goes back to the early and mid-1960s, when Dwight Allen, together with his colleagues, from the Stanford University in the USA first introduced it (Remesh \& Memorial, 2013). Microteaching was developed by these academics as a training programme aimed at improving prospective teachers' verbal and non-verbal skills when presenting lessons in the classroom. Microteaching provides student teachers with an opportunity to perk up their teaching skills by improving the various simple tasks called teaching skills (Moreeng, 2015; Anthonia, 2014).

As a result of the above microteaching has become an indispensable teacher training technique. Most universities use microteaching to equip their student teachers with the necessary teaching skills. However, several universities are experiencing challenges in presenting this crucial teacher training technique. The Central University of technology like most universities is also experiencing challenges in this regard. The challenges emanate from the large enrollments of students taking teaching as a profession. These large numbers of students pose a challenge about the infrastructures, resources and human resources needed to properly implement microteaching. An attempt is proposed by this paper to provide an ICT infused model that can enable universities to properly implement the microteaching processes.

\section{Understanding microteaching}

Microteaching is a skill-based analytical technique used to provide a connection between theory and practice in teaching. It is an activity that encourages engagement, growth, contextualization, and constant refinement of the acquired skills (Anthonia, 2014; Guelcher, Jackson, Necheles, 1970). Microteaching is a scaled-down simulated teaching practice where student teachers teach a small portion of a lesson to a small group of their classmates. Time, number of learners, content coverage and teaching skills are reduced when practicing microteaching. It employs real teaching situation for developing skills 
and helps to get deeper knowledge regarding the art of teaching (Remesh \& Memorial, 2013). It makes it possible to concentrate on specific teaching behaviour and to practice teaching under controlled conditions. In a microteaching session teaching of skills are carried out under a strictly controlled and supervised environment Student teachers present to a small group in 5-20 minutes on a selected and specific aspect of teaching (Anthonia, 2014; Ismail, 2011).

Microteaching has several objectives, among others to mention a few. Microteaching enable student teachers to learn and assimilate new teaching skills under controlled conditions. It enables student teachers to master several teaching skills. Also, it enables student teachers to gain confidence in teaching. Again, microteaching enable student teachers to analyse the complex process of teaching (Anthonia, 2014; Ismail, 2011).

\section{The problem statements}

The above is the ideal scenario on how microteaching should be carried out at universities. However, most universities cannot do that due to the large enrollments of students who wants to pursue teaching as a profession. These large enrollments pose a challenge regarding the infrastructure needed and the resources needed to carry out microteaching. Because of these large classes most universities are having another challenge about provision of feedback to student teachers. These institutions cannot have the supervisory teams as expected by the model above.

Like most universities the Central University of Technology (CUT) has a challenge of properly following microteaching processes and assessing the micro-lessons. According to the Revised Policy on Minimum Requirements for Teacher Education Qualifications of 2015 (Department of Higher Education and Training, 2015), microteaching is a subject offered by the Department of Educational and Professional Studies (DEPS). The specialisations classes are divided into four broad groups; namely languages group, EMS group, Natural Sciences \& Mathematics group and the Technology and Computer Sciences group. DEPS need to service each group regarding the lecturing of this subject (DHET, 2015). Each group comprises of a minimum of 150 students and one lecturer from DEPS is allocated a group. A result of this, it becomes practically impossible to do the microteaching process as discussed above. It therefore requires of the lecturers to come up with a strategy to ensure that the microteaching process is followed.

\section{ICT infused microteaching model}

In order to ensure that microteaching is properly done to respond to the above problems. The researcher implemented an ICT integrated approach to ensure that all the steps of a microteaching model are dealt with. First a workshop to all students teachers registered for the microteaching module at different levels was conducted. During these workshops the lecturers explained and demonstrate the microteaching process and the desired skill(s) for that semester.

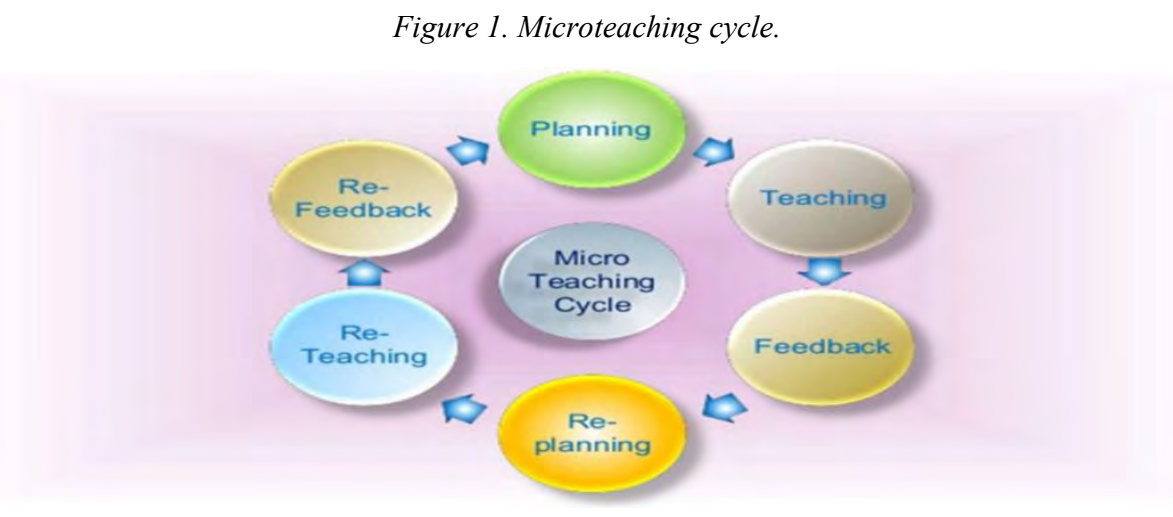

In addition to this, a video of the skill(s) was posted on the institution's Learner Management System (LSM), in the case of CUT, Blackboard/ eThuto to accommodate students that might have missed the workshop and also as a reference to students who would like a revision of the skill(s). During the workshop student teachers are afforded an opportunity to discuss and ask questions based on the demonstrated skill(s). After the workshop student teachers were requested to go through the following phases:

Phase 1: Student teachers were given a task to develop their individual micro-lessons. This process was done in the absence of the lecturer. 
Phase 2: Individual groups had to schedule a time slot for presentations where each member will be presenting (teach) to the other group members.

Phase 3: After this exercise, group members discussed their videos and gave each other feedback on their performances.

Phase 4: Group members had to choose one video that must be submitted to the lecturer for evaluation.

Phase 5: A panel of lectures chooses the best four to five videos which will be shown to the whole class during the lecturer's feedback workshop. The lecturer(s) together with the students will be discussing the skill(s).

All these phases will ensured that student teachers have done all the steps of the microteaching cycle. Again, going through these phases ensured that the lecturers have given opportunities to all student teachers to present a skill(s).

\section{Methodology}

In order to ascertain student teachers' perceptions of the introduced ICT infused microteaching. The methodology was structured as follows.

\subsection{Participants}

The subjects of this paper were 72 student teachers enrolled in the Microteaching level 3 module at CUT. Three groups of six students from the four areas of specialisations namely Maths \& Technology; Economic and Management Sciences; Languages; and Natural Sciences \& Computer Sciences. Each specialisation contributed a total of 18 student teachers i.e. 3 groups of six.

\subsection{Instrument}

A questionnaire was developed and used to collect the required data. The final version of the questionnaire included 24 items organised into six themes in accordance with the purpose of this study. The questionnaire was refereed by three other lecturers that are teaching microteaching at other levels. It used a five -point Likert scale of agreement with the variables ranging from Strongly Agree (5); Agree (4); Neutral (3); Disagree (2) and Strongly disagree (1).

\subsection{Data collection}

Data were collected towards the end of the first semester as Microteaching 3 module is a first semester module. The reason for conducting this research at the end of the semester was that by that time students would have finished all their micro-lessons and they would have received feedback from both peers and lecturers. The participants were invited to a microteaching laboratory to fill the questionnaire. The researcher personally administered the questionnaire and collected it from the participants. All participants were also assured that their responses will be kept confidential and that the data collected will only be used for purposes of this study. The researcher transcribed and analysed the responses.

\section{Findings of the study}

\subsection{Theme 1: ICT infused planning phase}

\begin{tabular}{|c|c|c|c|c|c|c|c|}
\hline & Statement & $\begin{array}{l}\text { Strongly } \\
\text { Agree }\end{array}$ & Agree & Neutral & Disagree & $\begin{array}{l}\text { Strongly } \\
\text { Disagree }\end{array}$ & Total \\
\hline 1 & $\begin{array}{l}\text { ICT equipment were very important } \\
\text { component of my planning phase }\end{array}$ & $38(53 \%)$ & $34(47 \%)$ & $0(0 \%)$ & $0(0 \%)$ & $0(0 \%)$ & $72(100 \%)$ \\
\hline 2 & $\begin{array}{l}\text { ICTs aroused my interest to plan } \\
\text { correctly }\end{array}$ & $39(54,2 \%)$ & $23(31,9 \%)$ & $7(9,7 \%)$ & $2(2,8 \%)$ & $1(1,4 \%)$ & $72(100 \%)$ \\
\hline 3 & $\begin{array}{l}\text { Using ICT enabled me to plan my } \\
\text { lessons thoroughly }\end{array}$ & $39(54,2 \%)$ & $23(31,9 \%)$ & $7(9,7 \%)$ & $3(4,2 \%)$ & $0(0 \%)$ & $72(100 \%)$ \\
\hline 4 & $\begin{array}{l}\text { It was easy use computers to prepare my } \\
\text { lessons, do better worksheets and } \\
\text { assessment sheets }\end{array}$ & $39(54,2 \%)$ & $23(31,9 \%)$ & $7(9,7 \%)$ & $3(4,2 \%)$ & $0(0 \%)$ & $72(100 \%)$ \\
\hline
\end{tabular}

When analyzing Theme 1, which is about ICT infused planning for microteaching, one issue emerges. The majority of student teachers unilaterally agreed that using ICT assisted them greatly to plan their lessons. This majority also indicated that the use of computers enabled them to do better worksheets and assessment sheets. However, there was a constant number of these student teachers who are not sure or are not totally convinced about the applications of ICT in this phase. This can be noticed by the responses provided under neutral or in statements 2,3 , and 4 . In short the majority of student teachers found out that the use of ICT is beneficial to them when planning the micro-lessons. 


\subsection{Theme 2: ICT infused teaching phase}

\begin{tabular}{|c|c|c|c|c|c|c|c|}
\hline & Statement & $\begin{array}{l}\text { Strongly } \\
\text { Agree }\end{array}$ & Agree & Neutral & Disagree & $\begin{array}{l}\text { Strongly } \\
\text { Disagree }\end{array}$ & Total \\
\hline 1 & $\begin{array}{l}\text { During this phase I was able to develop } \\
\text { confidence in my speaking ability }\end{array}$ & $30(41,7 \%)$ & $37(51,4 \%)$ & $5(6,9 \%)$ & $0(0 \%)$ & $0(0 \%)$ & $72(100 \%)$ \\
\hline 2 & $\begin{array}{l}\text { The use ICTs encouraged me to develop } \\
\text { my vocabulary }\end{array}$ & $30(41,7 \%)$ & $37(51,4 \%)$ & $5(6,9 \%)$ & $0(0 \%)$ & $0(0 \%)$ & $72(100 \%)$ \\
\hline 3 & $\begin{array}{l}\text { Using ICTs allowed me to apply ideas I } \\
\text { learned from different courses }\end{array}$ & $30(41,7 \%)$ & $37(51,4 \%)$ & $5(6,9 \%)$ & $0(0 \%)$ & $0(0 \%)$ & $72(100 \%)$ \\
\hline 4 & $\begin{array}{l}\text { ICTs encouraged me to present my } \\
\text { lessons clearly }\end{array}$ & $30(41,7 \%)$ & $37(51,4 \%)$ & $5(6,9 \%)$ & $0(0 \%)$ & $0(0 \%)$ & $72(100 \%)$ \\
\hline
\end{tabular}

In responses to statements on the ICT infused teaching phase the majority of participants indicated that they were in agreement to the fact that ICT greatly assisted them during the teaching phase of the model. A constant number of participants $6,9 \%$ of them were neutral about the use of ICT in the teaching phase of micro-lessons. This means that in general most student teachers were in agreement that the use of ICT is beneficial in the teaching phase of the micro-lessons.

\subsection{Theme 3: ICT infused Feedback phase}

\begin{tabular}{|c|c|c|c|c|c|c|c|}
\hline & Statement & $\begin{array}{l}\text { Strongly } \\
\text { Agree }\end{array}$ & Agree & Neutral & Disagree & $\begin{array}{l}\text { Strongly } \\
\text { Disagree }\end{array}$ & Total \\
\hline 1 & $\begin{array}{l}\text { ICT helped me develop awareness of my } \\
\text { teaching competence }\end{array}$ & $30(41,7 \%)$ & $37(51,4 \%)$ & $5(6,9 \%)$ & $0(0 \%)$ & $0(0 \%)$ & $72(100 \%)$ \\
\hline 2 & $\begin{array}{l}\text { ICTs helped me develop the actual } \\
\text { teaching skills I'll need later }\end{array}$ & $30(41,7 \%)$ & $37(51,4 \%)$ & $5(6,9 \%)$ & $0(0 \%)$ & $0(0 \%)$ & $72(100 \%)$ \\
\hline 3 & $\begin{array}{l}\text { ICTs gave me an opportunity to learn by } \\
\text { observing others }\end{array}$ & $30(41,7 \%)$ & $37(51,4 \%)$ & $5(6,9 \%)$ & $0(0 \%)$ & $0(0 \%)$ & $72(100 \%)$ \\
\hline 4 & $\begin{array}{l}\text { Made me aware of what makes a good } \\
\text { teacher }\end{array}$ & $30(41,7 \%)$ & $37(51,4 \%)$ & $5(6,9 \%)$ & $0(0 \%)$ & $0(0 \%)$ & $72(100 \%)$ \\
\hline
\end{tabular}

In response to the statements in Theme 3 most participants were in agreement that the use of ICT in feedback phase helped them with, among others, teaching competency, teaching skills and be aware of good teaching strategies. Like in the previous theme only $6,9 \%$ of the respondents were neutral about the statements. In short they were either in agreement or in disagreement with the statements. From the table above it is evident that most participants were in agreement that the use of ICT assisted them to provide and be provided with appropriate feedback.

\subsection{Theme 4: ICT infused re-planning phase}

\begin{tabular}{|c|c|c|c|c|c|c|c|}
\hline & Statement & $\begin{array}{l}\text { Strongly } \\
\text { Agree }\end{array}$ & Agree & Neutral & Disagree & $\begin{array}{l}\text { Strongly } \\
\text { Disagree }\end{array}$ & Total \\
\hline 1 & $\begin{array}{l}\text { This phase gave me an opportunity to improve } \\
\text { my lesson planning }\end{array}$ & $32(44,4 \%)$ & $37(51,4 \%)$ & $3(4,2 \%)$ & $0(0 \%)$ & $0(0 \%)$ & $72(100 \%)$ \\
\hline 2 & ICTs aroused my interest to plan correctly & $32(44,4 \%)$ & $37(51,4 \%)$ & $3(4,2 \%)$ & $0(0 \%)$ & $0(0 \%)$ & $72(100 \%)$ \\
\hline 3 & $\begin{array}{l}\text { Using ICT enabled me to plan my lessons } \\
\text { thoroughly }\end{array}$ & $32(44,4 \%)$ & $37(51,4 \%)$ & $3(4,2 \%)$ & $0(0 \%)$ & $0(0 \%)$ & $72(100 \%)$ \\
\hline 4 & $\begin{array}{l}\text { It was easy use computers to prepare my lessons, } \\
\text { do work sheets and assessment sheets }\end{array}$ & $32(44,4 \%)$ & $37(51,4 \%)$ & $3(4,2 \%)$ & $0(0 \%)$ & $0(0 \%)$ & $72(100 \%)$ \\
\hline
\end{tabular}

The responses for the re-planning phase are more positive that the ones of the planning phase. Unlike in the planning phase, no participants gave either a disagree or strongly disagree responses. The majority of the respondents were either in strongly agreement or gave an agreement response. Therefore the majority of the participants were in agreement that the use of ICT greatly assisted them to re-plan their micro-lessons.

\subsection{Theme 5: ICT infused re-teaching phase}

\begin{tabular}{|c|c|c|c|c|c|c|c|}
\hline & Statement & $\begin{array}{l}\text { Strongly } \\
\text { Agree }\end{array}$ & Agree & Neutral & Disagree & $\begin{array}{l}\text { Strongly } \\
\text { Disagree }\end{array}$ & Total \\
\hline 1 & $\begin{array}{l}\text { The re-teaching phase helped me discover and } \\
\text { fix my language problems }\end{array}$ & $32(44,4 \%)$ & $37(51,4 \%)$ & $3(4,2 \%)$ & $0(0 \%)$ & $0(0 \%)$ & $72(100 \%)$ \\
\hline 2 & $\begin{array}{l}\text { ICTs in this phase helped me better understand } \\
\text { different teaching methods }\end{array}$ & $32(44,4 \%)$ & $37(51,4 \%)$ & $3(4,2 \%)$ & $0(0 \%)$ & $0(0 \%)$ & $72(100 \%)$ \\
\hline 3 & $\begin{array}{l}\text { Using ICT helped me discover my teaching } \\
\text { strengths and weaknesses }\end{array}$ & $32(44,4 \%)$ & $37(51,4 \%)$ & $3(4,2 \%)$ & $0(0 \%)$ & $0(0 \%)$ & $72(100 \%)$ \\
\hline 4 & This phase encouraged me to develop autonomy & $32(44,4 \%)$ & $37(51,4 \%)$ & $3(4,2 \%)$ & $0(0 \%)$ & $0(0 \%)$ & $72(100 \%)$ \\
\hline
\end{tabular}


The responses are similar, in percentage, to the responses in Theme 4. The participants are in agreement with the statements. Only a small percentage, i.e. 4,2\%, of participants are neutral about the impact of ICT during the re-teaching phase.

\subsection{Theme 6: ICT infused re-feedback phase}

\begin{tabular}{|c|c|c|c|c|c|c|c|}
\hline & Statement & $\begin{array}{l}\text { Strongly } \\
\text { Agree }\end{array}$ & Agree & Neutral & Disagree & $\begin{array}{l}\text { Strongly } \\
\text { Disagree }\end{array}$ & Total \\
\hline 1 & $\begin{array}{l}\text { Using ICT in this phase enabled me to } \\
\text { critically assess and be assessed by my } \\
\text { peers }\end{array}$ & $32(44,4 \%)$ & $37(51,4 \%)$ & $3(4,2 \%)$ & $0(0 \%)$ & $0(0 \%)$ & $72(100 \%)$ \\
\hline 2 & $\begin{array}{l}\text { This phase improved and enhanced my } \\
\text { effectiveness as a teacher }\end{array}$ & $32(44,4 \%)$ & $37(51,4 \%)$ & $3(4,2 \%)$ & $0(0 \%)$ & $0(0 \%)$ & $72(100 \%)$ \\
\hline 3 & $\begin{array}{l}\text { It helped me to use technology } \\
\text { appropriately to predict classroom } \\
\text { problems }\end{array}$ & $32(44,4 \%)$ & $37(51,4 \%)$ & $3(4,2 \%)$ & $0(0 \%)$ & $0(0 \%)$ & $72(100 \%)$ \\
\hline 4 & $\begin{array}{l}\text { Criticism received from the peers guided } \\
\text { me to improve my standards }\end{array}$ & $32(44,4 \%)$ & $37(51,4 \%)$ & $3(4,2 \%)$ & $0(0 \%)$ & $0(0 \%)$ & $72(100 \%)$ \\
\hline
\end{tabular}

Just like in the feedback phase the participants are still in agreement that the use of ICT greatly assisted them in the re-feedback phase. They agreed that the use of ICT among others enabled them to critically assess and be assessed by their peers, ICT assisted them to predict classroom problems and the use of ICT in micro-lessons guided them to improve on their teaching standards.

\section{Conclusions}

The new ICT infused microteaching model was well received by both lecturers and student teachers at the CUT. Student teachers were requested to submit their videos as part of their assessment task one for the Microteaching Module for the second year of study of their B.Ed degree. Depending on the outcome of the results in terms of the desired outcomes, commitment, enjoyability from both students and lecturers. This model was used at CUT to curb the problems of infrastructure for presenting microteaching and the problem of ensuring that all student teachers in large classes are able to practice the required microteaching skills. The model can thus be recommended for use by other education institutions that are faced with similar microteaching problems as the ones of CUT.

\section{References}

Anthonia, O. I. 2014. Micro-Teaching: A technique for effective teaching. African Research Review, 8(4): 183-197.

Department of Higher Education and Training. 2015. National Qualifications Framework Act (67/2008): Revised policy on the Minimum Requirements for Teacher Education Qualifications. Government Gazette, 596(38487). Pretoria: Government Printer.

Guelcher, W., Jackson, T., Necheles, F. (1970). Microteaching and Teacher Training: A Refined Version.

Ismail, S.A.A., 2011. Student teachers' microteaching experiences in a preservice English teacher education program. Journal of Language Teaching and Research, 2(5), p.1043 -1051.

Merriam, S.B. \& Tisdell, E. J. 2016. Qualitative research: A guide to design and implementation. $4^{\text {th }}$ Edition. California: Jossey-Bass.

Moreeng,B. 2015. Microteaching. In Taole, M.J.2015. Teaching practice, perspectives and frameworks. Van Schaik Publishers: Pretoria

Morrison, B., 2010. Teacher training in China and the role of teaching practice. Retrieved June 16, 2019 from http://sunzil.lib.hku.hk/hkj/view/45/4500089/pdf

Oner, D. 2020. A virtual internship for developing technology pedagogical content knowledge. Australasian Journal of Educational Technology, 36(2), 27-42

Remesh, A.,Memorial, S.2013. Microteaching, and efficient technique for learning effective teaching. Journal of Research in Medical Sciences, 18(2), 158-163

Tunjera, N. \& Chigona, A. 2020. Teacher educators' appropriation of TPACK-SAMR Models for $21^{\text {st }}$ century pre-service teacher preparation. International Journal of Information and Communication Technology Education, 16(3), 126-140. 